\title{
THE JUDGMENT OF THE POLISH CONSTITUTIONAL TRIBUNAL OF 23 JUNE 2015 (NO. SK 32/14) CASE NOTE (PARTIALLY APPROVING)
}

\begin{abstract}
On 23 June 2015 the Polish Constitutional Tribunal issued the following judicial decision: "The provision of Article 79.1 (3b) of the Polish Act of 4 February 1994 on copyright and related rights ${ }^{1}$, in the way in which it entitles the right holder whose economic copyrights have been infringed to make request for remedy of the inflicted damage by payment, where the infringement is culpable, of triple the amount of the respective remuneration that would have been due as at the time of claiming it in exchange for the right holder's consent for the use of the work, shall be deemed unconstitutional as it is inconsistent with Article 64.1 and 2 in relation to Article 31.3 in relations to Article 2 of the Polish Constitution" ${ }^{2}$.
\end{abstract}

Keywords

alternative damage claim - copyright infringement - Polish Constitution - Polish Copyright Act

* Dr Daria Katarzyna Gęsicka is an Assistant Professor in the Chair of Civil and International Trade Law at the Faculty of Law and Administration of NCU in Torun. She graduated from both the Faculty of Law and Administration and the Faculty of Linguistic Sciences of NCU in Torun. She completed Postgraduate Studies on Copyright, Press, and Publishing Law at the Jagiellonian University in Cracow and a Summer Course on International Copyright Law at the University of Amsterdam. In 2013 she defended her $\mathrm{PhD}$ dissertation "Liability of ISPs for Third Party Content" and was awarded the academic degree of Doctor in Legal Sciences.

1 Act of 4.02.1994 on Copyright and Related Rights, Dz.U. [Polish Journal of Laws] 2006, No. 90, item 631; No. 94, item 658 and No. 121, item 843; of 2007 No. 99, item 662 and No. 181, item 1293; of 2009 No. 157, Item 1241 and of 2010 No. 152, item 1016; hereinafter referred to as the Polish Copyright Act.

2 The judgment of the Polish Constitutional Tribunal of 23.06.2015, SK 32/14, Orzecznictwo Trybunału Konstytucyjnego [Decisions of Constitutional Tribunal] 2015, no. 6A and its justification, referred to hereinafter as the justification. 


\section{THE SUBJECT OF THE JUDGMENT}

The subject of the commented judgment ${ }^{3}$ was the problem of the constitutionality of the Polish Copyright Act regulation on the alternative claim for damages. The provision allowed copyright holders to claim a lump sum - triple the amount of the respective remuneration (so called "royalty fee") - instead of the traditional civil damages. In fact, the Tribunal tried to find a balance between copyright protection and the economic interests of an infringer, both of which values are protected at constitutional level by means or Article 64.1 and 2 of the Polish Constitution as a part of a freedom to own ${ }^{4}$. Eventually, the Tribunal decided that the remedy was disproportionate in relation to the harm on the side of the right holder and as such constituted an unreasonable prejudice to the infringer's economic freedom ${ }^{5}$. While expressing the Author's partial approval of the judgment the Author wishes to present the subject-matter in question in a wider perspective. The Author is of the opinion that although the conclusion reached by the Tribunal deserves approval, there are significant loopholes in its justification.

\section{THE FACTUAL CIRCUMSTANCES OF THE CASE}

The defendant - a local cable television broadcaster - had retransmitted television programmes without proper authorization and, therefore, was sued by one of the Polish collective management societies - Polish Filmmakers Association (PFA). The court of first instance decided in favour of the plaintiff and adjudicated the damages. Both parties submitted appeals and both appeals were dismissed by the court of appeal. Then the case was settled twice by the Supreme Court and in both proceedings the Supreme Court decided in its judgments

\footnotetext{
3 Ibidem.

4 However, as stated by the Tribunal, the two values are not of an equal significance as the former should be ranked as more important than the latter. See 8.3. of the justification.

5 Compare with the Tribunal's communication after the judgment, available at: http://trybunal.gov.pl/sprawy-w-trybunale/katalog/s/sk-3214/ [last accessed: 25.10.2015].
} 
- the first of 15 June $2011^{6}$ and the second of 27 March $2013^{7}$ - that the case should be reviewed by the court of appeal. Significantly, the crux of the case was not whether the infringement had been committed or not, nor if there had been fault on the side of the defendant. The essence of the dispute was the manner of compensation for the damage - the choice was between two options: triple the amount of the due remuneration or the actual damage, and consequently the scope of an acceptable interference with the infringer's economic freedom in the view of the proportionality rule. In the third cassation complaint ${ }^{8}$ the defendant claimed the nonconformity of Article 79.1 (3b) of the Polish Copyright Act and Article 13 of the Enforcement Directive ${ }^{9}$ as well. Consequently, the Supreme Court decided to refer a preliminary question to the Court of Justice of the European Union (CJEU). Before the CJEU had a chance to answer the preliminary question, the Polish Constitutional Tribunal had issued a judgment on the constitutionality of the regulation. The judgment is the subject of this gloss.

\section{THE CLAIM IN THE VIEW OF THE TENETS OF CIVIL LAW}

The constitutionality of the remedy in question has been the subject of a controversy since the introduction of the Polish Copyright Act of 4 February $1994^{10}$. The controversies had been voiced long before the trial by civil law experts from Poland as well as other European countries, mainly as a part of the debate over the Enforcement Directive ${ }^{11}$, and were repeated in the proceedings before the Tribunal. The main argument against the regulation was that Article 79.1 (3b) was not compatible with the concept of damages in European civil law

\footnotetext{
6 The judgment of the Supreme Court of 15.06.2011, V CSK 373/10, Lex no. 885040.

7 The judgment of the Supreme Court of 27.03.2013, V CSK 203/23, Monitor Prawniczy [Legal Monitor] 2015, no. 2, pp. 83-84.

8 The judgment of the Supreme Court of 27.06.2014, V CKN 41/14, Lex no. 1504595.

9 Directive 2004/48/EC of the European Parliament and the Council of 29.04.2004 on the enforcement of intellectual property rights, O.J. L 157 of 30.04.2004, pp. 16-25, hereinafter referred to as the Enforcement Directive.

10 It is worth mentioning that until 2007 the claim was an alternative remedy as such. It was not a compensatory claim.

11 See 2.2.1. of the justification.
} 
and as such introduced a solution resembling punitive damages - a wellrecognized institution of the common law systems. Although the concept of civil liability evolved from the concept of criminal liability, and thus, at the beginning of its formation, was based on the right to retaliation, a monetary compensation similar to ransom $^{12}$ soon replaced the vengeance ${ }^{13}$. Significantly enough, the monetary ransom was due to an injured party irrespective of the fault on the side of an infringer. The evolution of the concepts of both civil and criminal liabilities in the eighteenth century brought yet further disassociation between the two regimes; however a few traces of the criminal origins of the civil liability can still be found, in particular, where the liability or its scope are related to the degree of fault on the side of an infringer or where the scope of damages is left to the court's sole discretion which allows the fault to be taken into consideration ${ }^{14}$. At the same time the construction of the claim in question results in consigning both the amount of the damages and the benefits on the side of an infringer to oblivion 15 .

In the contemporary continental law system, claims for damages are governed by certain rules, one of which is a comprehensive compensation doctrine - a rule according to which there should be a direct functional relation between the actual damage and the amount of damages adjudicated by the court. For example, according to Article 361 sec. 1 of the Polish Civil Code, an infringer is not liable for all the negative consequences of his/her conduct, but only for the normal ones. Hence, the predominant function of the damages is to compensate for the actual loss or lost profits. However, from time to time, when the public interest is at stake, the subsidiary role of the compensation is to prevent further infringements. For the above reasons, the punitive, or coercive, function

\footnotetext{
12 The role of the monetary compensation was to free an infringer from personal liability for the crime committed.

13 A. Nowak-Gruca, Cywilnoprawna ochrona autorskich praw majątkowych w świetle ekonomicznej analizy prawa [Protection of Economic Copyrights with Civil Law in the View of an Economic Legal Analysis], Warszawa: Wolters Kluwer Polska 2013, pp. 251-252, and the literature cited therein.

14 M. Kaliński, Odpowiedzialność odszkodowawcza - uwagi ogólne [Compensatory Liability General Remarks], [in:] A. Olejniczak (ed.), System Prawa Prywatnego. Prawo zobowiązań - częśś ogólna [Private Law System. Obligations Law - General Information], vol. 6, Warszawa: C.H. Beck 2008, pp. 17-18.

15 See 4.3. of the justification and the literature cited therein.
} 
of law has been reserved to criminal law, where the notion of punishment is closely tied up with the concept of fault. At the same time, the comprehensive compensation doctrine allows for the adjudication of the damages which correspond to the amount of the damage incurred, with the reservation that the damages must not exceed the amount of the injury in a way that an injured party could experience unjustified enrichment. In fact, most civil law countries allow plaintiffs to be compensated for actual harm and attach significance to compensation leaving a preventive and/or coercive function aside. Having solid grounds in the foundations of the continental law system, the rules such as comprehensive compensation doctrine and the normal chain of cause and effect seem to be justified in the light of the economic analysis of the law ${ }^{16}$ as well, owing to their resemblance to an ideal compensation doctrine.

The above-described tenets of civil law constituted a source of controversy concerning Article 79.1 (3b) of the Polish Copyright Act. The most questionable constructional element of the claim has been its flatrate character ${ }^{17}$ which is considered to be a reflection of a coercive function of law ${ }^{18}$. The solution which was adopted by the Polish legislature enabled the right holder whose economic copyrights had been infringed to claim for payment of double or, where the infringement was culpable, triple the amount of the respective remuneration. Therefore, such construction of the damage claim might be seen as detached from the actual damage and boiled down to a lump sum, and as such was found to be contrary to the comprehensive damages doctrine ${ }^{19}$. Even though, at times,

\footnotetext{
16 Nowak-Gruca, supra note 9, p. 252.

17 In fact, multiple damages are not damages in civil law terms, as they are detached from the harm incurred by an injured party.

18 P. Bogalski, Środki ochrony autorskich praw majątkowych oraz ich dochodzenie $w$ świetle prawa polskiego [Preventive Measures of Economic Copyrights and Their Claiming in Polish Law], Kraków: Kantor Wydawniczy Zakamycze 2003, p. 118.

19 A. Tischner, T. Targosz, Dostosowanie polskiego prawa własności intelektualnej do wymogów prawa wspólnotowego. Uwagi na tle projektu z dnia 24 maja 2006 r. ustawy o zmianie ustawy o prawie autorskim $i$ prawach pokrewnych oraz o zmianie innych ustaw [Adaptation of Polish Intellectual Property Law to the Requirements of European Law. Remarks Concerning the Draft of 24 May 2006 of the Act Amending the Act on Copyright and Related Rights and Some Other Acts ], Prace Instytutu Prawa Własności Intelektualnej UJ [Works of the Institute for Intellectual
} 
it is necessary to refer to non-judgmental (objective) circumstances while estimating the amount of the due damages, in particular when it is difficult or impossible to determine the exact amount of the actual losses or lost profit ${ }^{20}$, the situation of the claim in question is exceptional owing to the fact that it was the legislature who decided to replace traditional civil law tenets with non-judgmental factors such as the amount of the respective remuneration, and to multiply the amount ${ }^{21}$. Hence, the claim was found to be of a coercive character and contrary to the social justice rule expressed in Article 2 of the Polish Constitution. Having taken the specificity of copyright law into consideration, the Tribunal decided that the interference with the infringer's interests is far-reaching and incompatible with the minimal remedy rule.

\section{REMEDIES OF A COERCIVE CHARACTER}

The introduction of so-defined coercive character of the copyright infringement claim is not a solution peculiar to Polish copyright law; however the claim is unique in Polish IP law ${ }^{22}$. Numerous legal systems contain claims which entitle right holders to claim for damages exceeding

Property Law] 2007, no. 97, pp. 93-94. See also P. Podrecki, Środki ochrony praw własności intelektualnej [Intellectual Property Infringement Remedies], Warszawa: Lexis Nexis 2010, p. 325.

20 That is what Article 322 of the Polish Civil Procedure Code, Dz.U. [Journal of Laws] 2014, item 101 as amended, allows for, so perhaps there was no actual need for regulation as the one in Article 79.1 (3b) of the Polish Copyright Code.

21 A. Tischner, Harmonizacja prawapolskiego $z$ wymogami dyrektywy w sprawie egzekwowania praw własności intelektualnej [Harmonization of Polish law and the requirements of the Enforcement Directive], Monitor Prawniczy [Legal Monitor] 2005, no. 13/14, p. 691.

22 Multiple royalty fees cannot be claimed for any other IP infringement, including other infringements of exclusive rights such as patents or trademarks. The asymmetry in the system of IP claims has been extensively discussed in the literature on the subject matter. See the literature cited in 2.3 of the justification. However, multiplication of a lump sum is not so unusual in the system. For example, according to Article 394 of act of 23.04.1964 Polish Civil Code, Dz.U. [Journal of Laws] 2014, item 121 as amended, a party may make request for double the amount as a down payment if lack of performance or lack of due performance of an agreement is a consequence of circumstances for which the nonperforming party can be held liable and the affected party was the one who gave the down payment. In spite of the fact that the primary function of the down payment is to introduce an element of a discipline into a legal relationship, it should not be overlooked that there is a punitive element in it, too. Similar solutions can be found in provisions of labour or consumer law. 
the amount of the actual damage or damages, for which the amount of the actual losses or lost profits is irrelevant. In the majority of cases the introduction of coercive claims is supported by the ease of committing a copyright infringement, especially by means of electronic communication, and the fact that benefits arising from the infringement are much higher than traditional civil damages since the latter, being subject to the normal chain of cause and effect, do not cover all the negative consequences of the infringement. Another common argument in favour of giving right holders the privilege are evidential difficulties which might deter the right holder from engaging in a lawsuit.

Remedies of a coercive character can easily be found in the common law systems where the institution of statutory damages is deeply rooted in the system ${ }^{23}$. For example, the British legal system recognizes the institution of aggravated (additional) damages for flagrant acts of copyright infringement ${ }^{24}$ (Copyright, Designs, Patent Act, Article 97 (2). The Copyright Code of the United States entitles plaintiffs to claim for statutory damages in lieu of actual damages. The remedy is considered to be extraordinary, as the plaintiff is not required to prove either that he/she incurred any actual harm or that the defendant gained any profit due to the infringement ${ }^{25}$.

The multiple damages construction is acknowledged by several continental law countries. For instance in Slovenia the right holder is allowed to claim for triple the damages if the infringement is intentional or grossly negligent (Copyright and Related Rights Act of 2001, Article 108) and in Lithuania one may claim for double the damages, or triple where

\footnotetext{
23 Statutory damages are not a common solution in copyright legal systems around the world; nonetheless they exist in 24 of the 1770 WIPO member states, most of which are emerging and developing economies. Only five legal systems which recognize statutory damages have an advanced economy at the same time. These include the United States, Canada, Israel, the Republic of Korea, and Singapore. P. Samuelson, P. Hill, T. Wheatland, Statutory Damages: A Rarity in Copyright Laws Internationally, But For How Long?, Journal of the Copyright Society in the USA 2013, no. 60, p. 1, available at: https:/ / cyber.law.harvard.edu/people/tfisher/IP/Samuelson_SDs_2013.pdf [last accessed: 25.10.2015].

24 Compare with Podrecki, supra note 14, p. 309.

25 Samuelson, Hill, Wheatland, supra note 23, p. 1.
} 
the infringement is intentional ${ }^{26}$. In addition to that, one of the most representative droit d'auteur legal systems, France, has recently modified the manner of calculation of the damages. The modifications that were introduced into the French Intellectual Property Code in $2014^{27}$ redefined the concept of harm so that one can speak of a subtle convergence between the concept of the damages in the French IP law and punitive damages 28 . Article L.331-1-3 (1) of the French Intellectual Property Code ${ }^{29}$ states that the calculation of damages requires the court to take into consideration, and then justify in the judgment, each and every one of the following aspects:

- the negative economic consequences of the infringement, including the actual losses and/or lost profits incurred by an injured party;

- the moral harm suffered on the side of an injured party;

- the profits gained by an infringer, including savings due to intellectual investment.

Even though the last concept - of profits gained by an infringer - might be perceived as coercive in its nature due to the fact that it is quite distant from the actual harm, it is not as revolutionary as it might seem at first glance. The new definition of the prejudice implements Article 13 of the Enforcement Directive and the postulate of fairness as it does not allow the infringer to be enriched at the expense of an injured party. In fact, the remedy is of a compensatory character as the plaintiff cannot escape the traditional burden of proof requirements nor the obligation to justify the claim for damages.

26 See L.L. Stapleton, E-copyright Law Handbook, New York: Aspen Publishers Online 2002, available at: https://books.google.pl/books?id=NMHEZ_TBBXgC\&pg=SA13-PA57\&lpg= SA13-PA57\&dq=aggravated+damages+for+flagrant+acts+copyright+UK+law\&source=bl\&o ts=rZMLI7kTjy\&sig=9i8Yvp9uCZmLv0Q9TLXahjR06T8\&hl=pl\&sa=X\&ved=0CCIQ6AEwAG oVChMItrX1zLSGyAIV4_9yCh3rjw0N\#v=onepage\&q=aggravated $\% 20$ damages $\% 20$ for $\% 20 \mathrm{fl}$ agrant $\% 20$ acts $\% 20$ copyright $\% 20 \mathrm{UK} \% 20$ law \&f=false [last accessed: 20.9 .2015 ].

27 Act no. 2014-315 of 11.03.2014.

28 B. Spitz, France: New Legislation on Damages for Copyright Infringement, Kluwer Copyright Blog, post of 27.08.2014, available at: http:// kluwercopyrightblog.com/2014/08/27/francenew-legislation-on-damages-for-copyright-infringement/ [last accessed 2.07.2015].

29 Available at: http://www.legifrance.gouv.fr/affichCodeArticle.do;jsessionid=1D2E39E9 F86FB4C610EE98953C617527.tpdjo12v_3?idArticle=LEGIARTI000028716676\&cidTexte=LEGI TEXT000006069414\&dateTexte=20140802 [last accessed 1.07.2015]. 
Article L.331-1-3 (2) the French Intellectual Property Code 30 on the other hand contains an alternative remedy which has a coercive element. By means of the regulation the court may, at the request of an injured party, award damages in a lump sum. The amount of the alternative damages should not be lower than the amount of the royalty fees which would have been due had the infringer obtained the proper authorization. The claim for a lump sum, detached from the actual harm, bears an essential resemblance to the claim introduced by means of Article 79.1 (3b) of the Polish Copyright Act. Nevertheless, there is a significant difference between the two laws as the French solution does not mention multiplication of royalty fees.

\section{CONFORMITY WITH EUROPEAN LAW}

Another aspect in the discussion on multiple damages is its conformance with the Enforcement Directive ${ }^{31}$. Although its provisions do not explicitly state that multiplication of the respective remuneration is contrary to European copyright law, the statement cannot be treated as an argument in the debate. The argument is encumbered with a logical aberration ${ }^{32}$. Also, motive 26 of the Enforcement Directive explains that "as an alternative, for example, where it would be difficult to determine the amount of the actual prejudice suffered, the amount of the damages might be derived from elements such as the royalties or fees which would have been due if the infringer had requested authorization to use the intellectual property right in question. The aim is not to introduce an obligation to provide for punitive damages, but to allow for compensation based on an objective criterion while taking account of the expenses incurred by the right holder, such as the costs of identification and research". Thus the directive itself sets grounds for an alternative claim

\footnotetext{
30 Available at:

http:/ / www.legifrance.gouv.fr/affichCodeArticle.do;jsessionid=1D2E39E9F86FB4C610EE98 953C617527.tpdjo12v_3?idArticle=LEGIARTI000028716676\&cidTexte=LEGITEXT0000060694 $14 \&$ dateTexte $=20140802$ [last accessed 2.07.2015].

31 See Podrecki, supra note 14, p. 299 et seq.; Nowak-Gruca, supra note 9, p. 252; Tischner, supra note 16, p. 691.

32 Similarly Podrecki, supra note 14, p. 299.
} 
and, what is more, determines that the amount of the damages might be based on criteria such as remuneration, as does Article 13 (1b) of the Directive. Importantly, the law makes admissibility of the claim for alternative damages dependent on fault on the side of the infringer, by stating that the regulation applies to the infringer who knowingly or with reasonable grounds to know, engages in an infringing activity. The nonconformity between Article 13 of the Enforcement Directive and Article $79.1(3 b)$ of the Polish Copyright Act is the multiplication element as well as its application to copyright and related rights only, and that has been the main bone of contention.

\section{Proportionality RULE}

The Polish Constitutional Tribunal decided that the regulation in question does not fulfil the proportionality requirements and as such is discordant with Article 31 (3) and Article 2 of the Polish Constitution ${ }^{33}$. Even though the Tribunal accepted the multiplication mechanism as such, they found it unacceptable for the right holder to claim damages the amount of which is entirely detached from the size of the actual damage and as such totally arbitrary ${ }^{34}$. Lack of proportion between the two - the damages and the actual damage - being a consequence of a fixedrate element by reference to the respective remuneration, results in a disproportionally severe sanction imposed on an infringer. Therefore, the Tribunal found the regulation in question to constitute an unjustified limitation of the economic freedom of an infringer. As mentioned before, regardless of the Tribunal's judgment in the subject matter, on 15 May 2015 the Polish Supreme Court decided to refer to the Court of Justice of the European Union a preliminary question concerning the conformity of Article 79.1 (3b) of the Copyright Act and Article 13 of the Enforcement Directive so, perhaps, if CJEU decides so, we will soon see an assessment of the regulation from a European perspective.

33 The Constitution of the Republic of Poland of 2.04.1997, Dz.U. [Journal of Laws] 1997, No. 78, item 483.

34 See 8.5.2. of the justification. 
Despite firm logic and strong civil-law-based arguments behind the decision of the Tribunal, there are numerous and quite sound counterarguments. First of all, the peculiar character of copyright law and its subject justify more of a preventive function of the damage claim. Works under copyright protection, unlike subjects of industrial property, are not subject to registration. To be committed, copyright infringements do not require any expert knowledge on the side of an infringer and therefore are committed on a larger scale than other IP infringements. Secondly, the negative consequences of an infringement (including those within the normal chain of cause and effect) are usually far-reaching and some of them cannot be measured by traditional criteria applied in the calculation of damages. For example, a pre-release leak of an audiovisual work not only results in actual damages and lost profits, but can also lead to depreciation of the work ${ }^{35}$. The benefits arising from the infringement significantly outbalance the risk of being held liable ${ }^{36}$ and it seems that even the possibility of being obliged to pay triple the amount of the respective remuneration does not act as an efficient deterrent. Therefore, intensification of the preventive role of remedies might be well-founded in relation to mass infringements such as piracy or counterfeiting 37 . Last but not least, the coercive nature of the remedy

\footnotetext{
35 See how the pre-release leak of the film "The Expendables 3" affected the box-office revenue. J. Bailey, The Impact of Pre-Release Piracy, Plagiarism Today.com, post of 31.07.2014, available at: https://www.plagiarismtoday.com/2014/07/31/impact-pre-release-piracy/ [last accessed 2.07.2015] and S. Castillo, Pre-Release Movie Piracy Strikes Again, Copyright Alliance.org, post of 28.07.2014, available at: http://copyrightalliance.org/2014/07/prerelease_movie_piracy_strikes_again\#.VZ6ZWfntlBc [last accessed 2.07.2015]. See also a more general study on the impact of pre-release film piracy on box-office revenue by L. Ma, A. Montgomery, P. Vir Singh, M.D. Smith, An Empirical Analysis of the Impact of Pre-Release Movie Piracy on Box-Office Revenue, Pittsburgh: Copyright Alliance 2014, pp. 1-30.

36 Such a conclusion can be drawn from the ever-growing piracy numbers. See a report on the impact of the piracy of video material on the economy of Poland according to which 7.5 million Poles make use of websites and on-line services offering illegal video content, PricewaterhouseCooper Polska Sp. z o.o., Analiza wptywu zjawiska piractwa treści wideo na gospodarke w Polsce. Raport [The Analysis of the Impact of Piracy of Video Material on the Polish Economy. A Report], available at: http://www.pwc.pl/pl_PL/pl/publikacje/piractwo/ analiza_wplywu_zjawiska_piractwa_tresci_wideo_na_gospodarke_w_polsce_raport_pwc.pd f [last accessed 27.06.2015].

37 A. Kur, Prevention-Cui Bono?, [in:] A. Kur, S. Luginbühl, E. Waage (eds), “... und sie bewegt sich doch!": Patent Law on the Move: Festschrift für Gert Kolle und Dieter Stauder zum 65. Geburtstag am 25. April 2005 und 20. Oktober 2005, Cologne: Carl Heymanns 2005, p. 386 et seq.; cited after Podrecki, supra note 14, p. 304.
} 
can be justified with the lucrative fault doctrine, a doctrine of French origins which has been applied as an argument for any kind of private punishment in French law ${ }^{38}$. Although the Tribunal acknowledged the sodefined specificity of copyrighted works, it also noticed that the legal position of right holders has changed recently so that they are no longer the weaker party in a legal relationship ${ }^{39}$. More and more often right holders are legal entities or enterprises who have access to professional legal services. That being true, it is necessary to emphasize that not all right holders are professionals and those non-professionals still need to be protected. That is why the role of Article 322 of the Polish Civil Procedure Code is so significant. The provision might be applied to eliminate problems concerning the determination of the precise size of the damage.

\section{CONCLUSIONS}

To sum up, the judgment of the Polish Constitutional Tribunal deserves to be partially approved of. The regulation of Article 79.1 (3b) of the Polish Copyright Act in the way it entitles the plaintiff to claim for damages of triple the amount of the respective remuneration in the case of economic copyrights infringement where the infringement is culpable might not only be unconstitutional since the regulation could be deemed incompatible with European law, including the Enforcement Directive. A claim based on the multiplication of a lump sum might indeed have a punitive character in the particular circumstances of a case - that is when the damages adjudicated by the court would exceed the amount of the actual loss or lost profit in such a way that they become a punishment to the infringer. The alternative damages claim was introduced by the legislature in order to expedite proceedings and equip rights holders with an evidentially simplified claim. The introduction of a non-judgmental element was also dictated by the immaterial character of copyrighted works which might impede calculation of the damages. What is more, it is not always true that the amount of the actual damage

\footnotetext{
38 See Podrecki, supra note 14, p. 311 and the literature cited therein.

39 See 8.5.2. of the justification.
} 
is smaller than three times the damages, but in most cases it is. In addition to that, since the Tribunal saw the punitive character of the claim in the fact that it is detached from the actual damage and interferes with the infringer's economic rights in an arbitrary manner, it has to be noted that, if there was an alternative claim based on a construction of traditional civil damages, including the requirement to indicate the exact size of the damage, the claim would not differ at all from the one stipulated in Article 79.1 (3a) of the Polish Copyright Act ${ }^{40}$. Even though the Tribunal said that the construction of an alternative damage claim based on a lump sum is acceptable, the size of the damage should be the limit. However, if so it would not make civil proceedings in copyright infringement cases more efficient, so the legislative purpose of the regulation would not be reached. The number of cassation claims addressed to the Supreme Court and the claim to the Constitutional Tribunal as well as the number of claims for alternative damages prove that there is a need for such simplification. What might provoke second thoughts is the fact that, even if the Tribunal addressed the claim for multiple compensation for lost remuneration, the judgment applies only to a part of the claim ${ }^{41}$. It affects solely the construction of the claim where the legislature made the accessibility of the claim dependent on the fault of the infringer. That is where the Tribunal saw a lack of proportionality, whereas the part of the regulation upon which the plaintiff might claim damages of double the amount of the respective remuneration remained intact. It might be deduced that the Tribunal indirectly advocated an alternative damage claim that would refer to a single lump sum (royalty fee). Nevertheless, such an approach might turn out to become an obstacle for non-professional right holders, mostly the authors themselves,

\footnotetext{
40 It has been noted by P. Machnikowski that the construction of the claim made it difficult to determine the relations between Article 97.1 (3) of the Polish Copyright Act and the provisions of the Polish Civil Code. P. Machnikowski, Funkcja prewencyjna roszczeń pieniężnych powstających $w$ razie naruszenia praw własności intelektualnej [Preventive Function of the Pecuniary Claims in Case of Intellectual Property Infringements], [in:] A. Matlak, S. Stanisławska-Kloc (eds), Spory o wtasność intelektualną. Księga jubileuszowa dedykowana Profesorom Januszowi Barcie i Ryszardowi Markiewiczowi [Disputes over the Intellectual Property. The Book Dedicated to Professors Janusz Barta and Ryszard Markiewicz], Warszawa: Wolters Kluwer Polska 2013, p. 512.

41 The Tribunal in making its decision was bound by the legal bases and the demand as formulated in the claim.
} 
to be compensated for the entire damage. The judgment thus lacks consistency as well as proper justification and that is the reason for the Author's only partial approval of it. 